\title{
Solar control solutions for reducing overheating risks in retrofitted Danish apartment buildings from the period 1850- 1900 - A simulation-based study
}

\author{
Daria Zukowska*, Myrto Ananida, Jakub Kolarik, Mandana Sarey Khanie, and Toke Rammer Nielsen \\ Technical University of Denmark, Department of Civil Engineering, Brovej 118, 2800 Kgs. Lyngby, Denmark
}

\begin{abstract}
Advancing energy efficient renovation solutions in residential buildings necessitate adopting high-insulation and airtightness to avoid heat loss through transmission and infiltration, which can result in overheating. Elevated indoor temperatures have been proved to have a highly negative effect on occupants' health and well-being. Energy efficient solutions to the problem with overheating include limiting the solar heat gains through the glazed parts of the facade and effective ventilation. A typical Danish residential apartment building from 1850-1900 recently refurbished, was modelled with five different solar shading devices and three typical ventilation solutions. External solar shading could efficiently reduce overheating below the limits specified by the national building regulations in all tested cases. The marquisolette reduced the number of occupied hours with temperature above $27{ }^{\circ} \mathrm{C}$ by $\min .85 \%$, the external venetian blinds by min. $81 \%$, and the drop arm awning by min. $74 \%$ compared to the situation without solar shading. The internal solar shading as venetian blinds and roller blind could reduce the overheating hours by $20-40 \%$, which was efficient only in combination with mechanical ventilation in case of south and east building orientations.
\end{abstract}

\section{Introduction}

The building sector is responsible for approx. $40 \%$ of the total energy consumption and $36 \%$ of the $\mathrm{CO}_{2}$ emissions in Europe [1]. Currently, about $35 \%$ of the EU's buildings are over 50 years old and almost $75 \%$ of the building stock is energy inefficient, while only $0.4-1.2 \%$ (depending on the country) of the building stock is renovated per year [2]. Therefore, renovation of existing buildings is essential for significant energy savings. It can potentially reduce the EU's total energy use by 5-6\% and lower the $\mathrm{CO}_{2}$ emissions by about 5\% [2].

Commonly applied renovation approach aims to limit heat transfer through the building envelope by adding thermal insulation and tightening the envelope. These solutions lead to energy savings during the heating season, but limited infiltration can cause elevated indoor temperatures during periods with high solar radiation [3]. Glazing in buildings is primarily installed to admit daylight and allow view to the outside but it allows solar radiation to enter the building, which in summer may be excessive and result in overheating. Normal clear window glass allows short-wave solar radiation to get into an interior space, where the radiation is absorbed. The interior then radiates long wave, i.e. thermal radiation, which is trapped in the building as glass is opaque to this long wave radiation. Consequently, the indoor air temperature rises. This is called the "greenhouse effect".
Elevated indoor temperatures have been proved to have a highly negative effect on occupants' health, wellbeing and productivity [4]. The issue becomes more important as the number of people working from home increases [5] and the external temperatures increase due to climate changes [6].

Energy efficient solutions to the problem with overheating in dwellings include limiting the solar heat gains through the glazed parts of the facade [3] and effective ventilation [7]. Internal and external solar shading or solar control glazing can be used very effectively to keep rooms in private houses and apartments cooler during high solar radiation periods and reducing, or maybe even eliminating, the elevated indoor temperatures and need for air-conditioning. Several studies indicated that external solar shading devices are more efficient than internal shading because they reduce solar transmittance to the indoor space [3]. However, the internal solar shading gives occupants possibility to prevent a discomfort due to glare of direct sunlight. The ES-SO 2014 "Cost Efficient Solar Shading Solutions in High Performance Buildings" study [8] demonstrated that dynamic solar shading leads to cooling energy savings of up to $62 \%$ for a south-west facade for the climate of Stockholm. At the same time, a few studies reported that peoples' health, well-being and social interaction benefits from daylight exposure [9], therefore optimal use of solar shading is essential. Ventilation has

*Corresponding author: dz@byg.dtu.dk 
been proven to be efficient in lowering the indoor temperature in moderate climates [10]. The term "ventilative cooling" has become popular in recent years and it refers to the use of natural or mechanical ventilation strategies to cool indoor spaces by effective use of outside air [7]. Ventilative cooling reduces the energy consumption of cooling systems while maintaining thermal comfort. In rural and suburban locations, the solution may be to use window opening to help to cool dwellings but only in case when the outside temperature is lower than the inside temperature. In urban location, the possibility to open window can be limited due to noise, pollution or security concern.

The objective of the work described in this paper was to evaluate the potential of different solar shading devices combined with typical ventilation solutions to reduce indoor temperature excess in a renovated Danish apartment building from the period 1850-1900.

\section{Methods}

\subsection{Building and its surroundings}

In the present study an apartment in a historical residential 5-storey building located in Copenhagen (Figure 1) was modelled in IDA Indoor Climate and Energy (IDA ICE) software [11] before and after renovation. The building represents a building type from the period 1850-1900 common in Danish cities. The building comprises parts of a rectangular arrangement of similar buildings with the backside facing to the courtyard in the middle and the front facade facing the street with other buildings of the same height. To simulate the most critical situation due to solar heat gains, the surrounding buildings were removed - a case when e.g. the building is facing a square (Figure 2). For the comparison, however, simulations with the surrounding buildings were also performed. Those cases presented the real situation where the original building is placed in a narrow street canyon with a similar building located in a distance of $8.8 \mathrm{~m}$. (Figure 3 ). The building facade and construction were modelled as the original building with external walls made of bricks, inner walls of timber construction and bricks, and wooden floor construction.

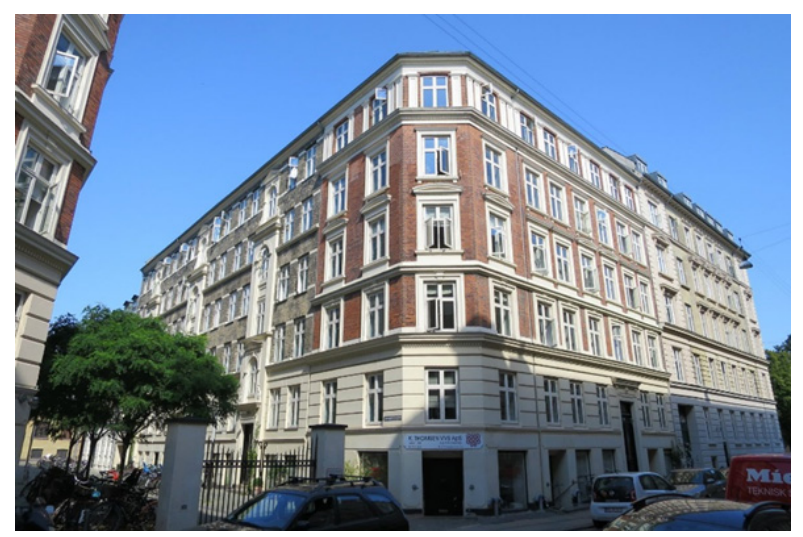

Fig. 1. Case study building.
The simulated apartment was located on the $2^{\text {nd }}$ floor of the building and consisted of a kitchen, living room, bedroom, small bathroom and hall - a total gross floor area of $56.6 \mathrm{~m}^{2}$ (Figure 4). The apartment was simulated in three different orientations - with the living room facing west, east and south.

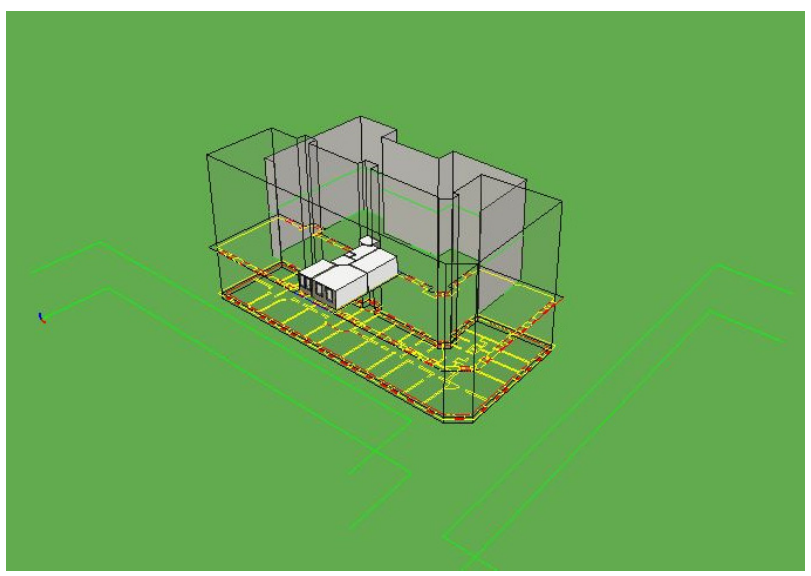

Fig. 2. Building model without surrounding buildings.

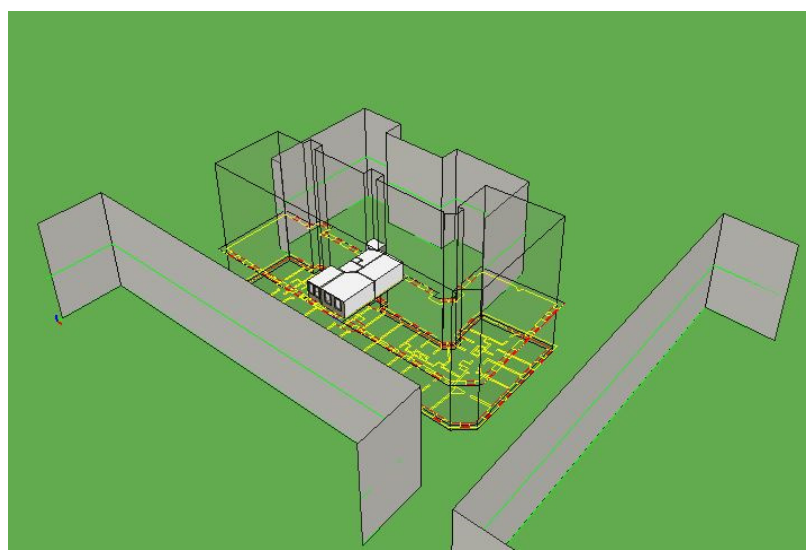

Fig. 3. Building model with surrounding buildings.

The windows in the apartment before and after renovation were assumed to be the same - clear double pane energy windows (4-12Ar-S(3)4) with the heat transfer coefficient of glazing $\mathrm{U}_{\mathrm{g}}=1.3 \mathrm{~W} /\left(\mathrm{m}^{2} \cdot \mathrm{K}\right)$, light transmittance $\mathrm{T}_{\mathrm{vis}}=82 \%$, direct solar energy transmittance ST $=57 \%$, solar heat gain coefficient $\mathrm{g}=$ $65 \%$ and the heat transfer coefficient of the wooden window frame of $\mathrm{U}_{\mathrm{f}}=1.3 \mathrm{~W} /\left(\mathrm{m}^{2} \cdot \mathrm{K}\right)$. The windows in the living room and in the bedroom consisted of four openable parts where the two lower parts counted for $2 / 3$ of the window size. The fraction of the frame to the total window area was calculated to $39 \%$ for windows in the living room and the bedroom, and $28 \%$ in the kitchen.

Energy renovation for the simulated building included an addition of $95 \mathrm{~mm}$ of internal thermal insulation and limited infiltration (see section 2.4). The heat transfer coefficient for the external wall changed from $\mathrm{U}_{\text {wall }}=1.06 \mathrm{~W} /\left(\mathrm{m}^{2} \cdot \mathrm{K}\right)$ before renovation to $U_{\text {wall }}=$ $0.30 \mathrm{~W} /\left(\mathrm{m}^{2} \cdot \mathrm{K}\right)$ after renovation. Due to the architectural value of the facades in this type of buildings, internal insulation was assumed. 
The building model was located in Copenhagen, Denmark. The simulation period was set from the $1^{\text {st }}$ of January to the $31^{\text {st }}$ of December 2010 using weather data by the Danish Reference Year, DRY 2013 [12].

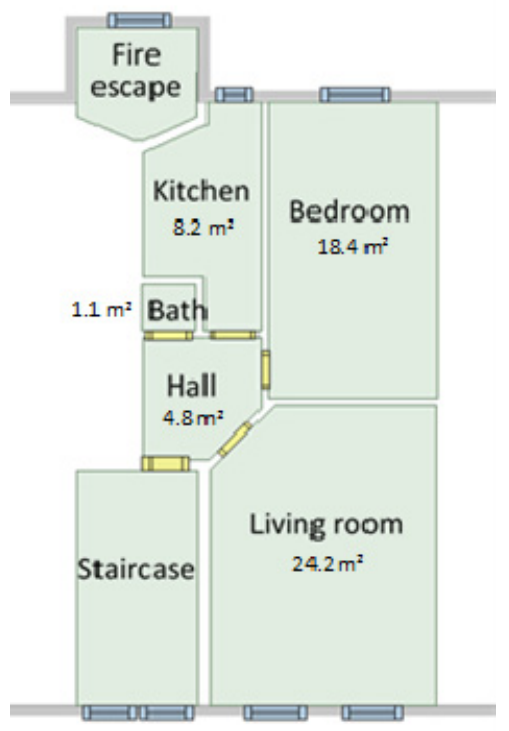

Fig. 4. Layout of simulated apartment.

\subsection{Internal heat loads}

The apartment was assumed to be occupied by two adults employed with standard work hours. The same occupancy schedules for the individual rooms were assumed during weekdays and weekends in order to make the case simpler and due to broad variations in people's activities during weekends. The assumed occupancy schedules for each room are shown in Table 1. The constant total internal heat load of $5 \mathrm{~W} / \mathrm{m}^{2}$ of the heated floor area (i.e. with external walls), including occupants and equipment/lighting, was assumed in the models following the assumption used in the Danish energy frame calculations for dwellings [13]. The heat load from the occupants for a whole year for each room was determined based on simulations with the occupancy schedules as in Table 1. The heat load from the equipment and lighting for each room was calculated as the difference between the yearly total heat load (Table 2) and the yearly heat load from the occupancy (Table 1) and was assumed to be constant during the whole year.

Table 1. Occupancy schedules and heat loads for the different rooms.

\begin{tabular}{|c|c|c|c|c|}
\hline Room & Occup. & $\begin{array}{c}\text { Metab. } \\
\text { rate } \\
\text { met }\end{array}$ & Schedule & Heat load \\
kWh/year \\
\hline Bedroom & 2.0 & 0.9 & $22: 00-7: 00$ & 621 \\
\hline $\begin{array}{c}\text { Living } \\
\text { room }\end{array}$ & 1.5 & 1.0 & $\begin{array}{c}7: 00-8: 30 \\
16: 00-22: 00\end{array}$ & 430 \\
\hline Bathroom & 0.5 & 1.2 & $7: 00-8: 30$ & 35 \\
\hline Kitchen & 0.5 & 1.4 & $17: 00-22: 00$ & 135 \\
\hline Hall & - & - & - & - \\
\hline
\end{tabular}

Table 2. Heat loads and schedules for equipment and lighting for the different rooms.

\begin{tabular}{|c|c|c|c|c|}
\hline Room & $\begin{array}{c}\text { Total heat } \\
\text { load }\end{array}$ & \multicolumn{2}{|c|}{$\begin{array}{c}\text { Heat load from } \\
\text { equipment } \\
\text { kWh/year }\end{array}$} & Schedule \\
$\mathbf{k W h} / \mathbf{y}$ (y) & $\mathbf{W}$ & \\
\hline Bedroom & 807 & 186 & 21.3 & Const. \\
\hline $\begin{array}{c}\text { Living } \\
\text { room }\end{array}$ & 1060 & 630 & 71.9 & Const. \\
\hline Bathroom & 47 & 12 & 1.4 & Const. \\
\hline Kitchen & 357 & 222 & 25.4 & Const. \\
\hline Hall & 209 & 209 & 23.8 & Const. \\
\hline
\end{tabular}

*Total heat load is calculated based on the assumption of 5 $\mathrm{W} / \mathrm{m}^{2}$ of the heated floor area.

\subsection{Moisture load from activities}

The moisture production from typical activities occurring in the apartment was set to $2.6 \cdot 10^{-4} \mathrm{~kg} / \mathrm{s}$ in the bathroom and $1.10 \cdot 10^{-4} \mathrm{~kg} / \mathrm{s}$ in the kitchen [14], and it follows the occupancy schedules for these two rooms.

\subsection{Windows and doors opening}

A crude estimate of the occupants' window opening behaviour was simulated using temperature control by a proportional-integral (PI) controller: $\mathrm{T}_{\text {set-point }}=23{ }^{\circ} \mathrm{C}, \mathrm{K}$ $=0.3$ with additional conditions with respect to outdoor temperature: $T_{\text {outdoor }} \leq\left(T_{\text {room }}-2\right) \mathrm{K}$ and the presence of at least one of the occupants in the apartment. The effective window opening area was assumed to be $60 \%$ according to [15] and $15 \%$ during night-time. It was assumed that the upper parts of the window in the living room and the bedroom were never open (inconvenient due to a high position of these parts), so $60 \%$ of the window opening was implemented to the lower parts and for the whole window in the kitchen. Only one of the two windows in the living room was set to open.

The doors to all rooms were kept closed during the whole simulation period to avoid unrealistic large airflows between the rooms. A leak with an area of $0.01 \mathrm{~m}^{2}$ and discharge coefficient $\mathrm{C}_{\mathrm{d}}=0.65$ was placed at each door.

\subsection{Ventilation and infiltration}

The building before renovation was assumed to be naturally ventilated (case Non-renovated NV) with fixed infiltration of $0.5 \mathrm{l} /\left(\mathrm{s} \cdot \mathrm{m}^{2}\right)$ of the heated floor area.

The building after renovation was simulated with three typical ventilation solutions used in Danish dwellings. The naturally ventilated building (case Renovated NV) was modelled with fixed infiltration of $0.3 \mathrm{l} /\left(\mathrm{s} \cdot \mathrm{m}^{2}\right)$ of the heated floor area corresponding to the minimum fresh air supply required by the Danish building code [16]. Additionally, two balanced mechanical ventilation systems were simulated constant air volume (abbreviated as $\mathrm{CAV}_{\max }$ ) and variable air volume (abbreviated as $\mathrm{VAV}_{\mathrm{RH}}$ ). In the $\mathrm{CAV}_{\max }$ system the airflows were determined to fulfil 
two requirements from the Danish building code [16]. The amount of $35 \mathrm{l} / \mathrm{s}$ was extracted (bathroom $20 \mathrm{l} / \mathrm{s}$ and kitchen $15 \mathrm{l} / \mathrm{s}$ ) and the same total amount of air was supplied to the habitable rooms. The $\mathrm{VAV}_{\mathrm{RH}}$ ventilation system represented decentralized ventilation solution with airflows controlled according to the relative humidity (RH) measured in the exhaust duct. The minimum supply airflows into the habitable rooms corresponded to $0.3 \mathrm{l} /\left(\mathrm{s} \cdot \mathrm{m}^{2}\right)$, while the maximum airflows were determined to fulfil the requirements to the amount of exhaust air from a bathroom and a kitchen [16]. The $\mathrm{VAV}_{\mathrm{RH}}$ system was controlled by a proportional $(\mathrm{P})$ controller: $\mathrm{RH}_{\text {set-point }}=50 \%$, P-band $=$ $20 \%$. The airflows for the two mechanical ventilation systems can be seen in Table 3 .

Wind driven infiltration characterized by air tightness of $1 \mathrm{l} /\left(\mathrm{s} \cdot \mathrm{m}^{2}\right)$ of the heated floor area at $50 \mathrm{~Pa}$ was considered for the mechanically ventilated cases.

Table 3. Airflows in $\mathrm{CAV}_{\max }$ and $\mathrm{VAV} \mathrm{V}_{\mathrm{RH}}$ systems for different rooms (in blue colour supply and in green colour extraction).

\begin{tabular}{|c|c|c|c|c|c|c|}
\hline \multirow[t]{3}{*}{ Room } & \multirow{2}{*}{\multicolumn{2}{|c|}{$\begin{array}{c}\text { CAV }_{\text {max }} \\
\text { Airflow }\end{array}$}} & \multicolumn{4}{|c|}{ VAV $_{\text {RH }}$} \\
\hline & & & \multicolumn{2}{|c|}{ Min. airflow } & \multicolumn{2}{|c|}{ Max. airflow } \\
\hline & $1 /\left(s \cdot m^{2}\right)$ & l/s & $1 /\left(s \cdot m^{2}\right)$ & $\mathbf{l} / \mathbf{s}$ & $\mathbf{l} /\left(\mathbf{s} \cdot \mathbf{m}^{2}\right)$ & $1 / s$ \\
\hline Bedroom & 1.80 & 1.9 & 0.87 & 0.9 & 1.80 & 1.9 \\
\hline Living room & 1.80 & 33.1 & 0.87 & 16.1 & 1.80 & 33.1 \\
\hline Bathroom & 3.15 & 15.0 & 1.53 & 7.3 & 3.15 & 15.0 \\
\hline Kitchen & 2.45 & 20.0 & 1.19 & 9.7 & 2.45 & 20.0 \\
\hline Hall & - & - & - & - & - & - \\
\hline
\end{tabular}

A typical air handling unit used for residential ventilation in Denmark fulfilling the requirements from the Danish building regulations [16] was simulated. It consisted of heat recovery (the dry temperature efficiency of $85 \%$ at maximum airflow) and two fans (the max. specific fan power for each fan of $0.5 \mathrm{~kJ} / \mathrm{m}^{3}$ ). Neither heating nor cooling coil was used. The set point for the supply temperature was $18{ }^{\circ} \mathrm{C}$. The primary energy factor for electrical power was set to 2.5 [16].

\subsection{Heating system}

Idealized heating units ensuring the heating temperature set point of $20^{\circ} \mathrm{C}$ in all rooms of the apartment $\left(16^{\circ} \mathrm{C}\right.$ in the staircase and fire escape) were used in all cases for the heating season assumed from the $1^{\text {st }}$ of October to the $30^{\text {th }}$ of April. The heating was supplied by district heating with a primary energy factor of 0.8 [16].

\subsection{Solar shading}

A case without solar shading and five cases with different solar shading devices were tested for the building before renovation and after renovation, and in combination with three different ventilation strategies. The solar shading devices were modelled using standard IDA ICE component models. The use of external solar shading in this type of buildings is limited due to the architectural heritage value of the facades and therefore light colours of shadings were chosen, as the one integrating with the building appearance most. The properties of the tested solar shadings are listed in Table 4.

Table 4. Properties of tested solar shading devices.

\begin{tabular}{|c|c|c|c|c|}
\hline Placement & Shading device & Picture & Colour & $\begin{array}{r}\text { Material } \\
\text { properties }\end{array}$ \\
\hline \multirow{3}{*}{ External } & Awning blinds & & $\begin{array}{c}\text { Fabric: Grey- Beige } \\
\text { (Warema 5860) }\end{array}$ & $\begin{array}{l}\mathrm{T}_{\mathrm{vis}}=0 \% \\
\mathrm{R}=13 \%\end{array}$ \\
\hline & Marquisolette & & $\begin{array}{c}\text { Fabric: Grey- Beige } \\
\text { (Warema 5860) }\end{array}$ & $\begin{array}{l}\mathrm{T}_{\mathrm{vis}}=0 \% \\
\mathrm{R}=13 \%\end{array}$ \\
\hline & Venetian blinds & & $\begin{array}{l}\text { C-shaped slats } \\
\text { White }\end{array}$ & $\begin{array}{l}\mathrm{T}_{\mathrm{vis}}=0 \% \\
\mathrm{R}=74 \%\end{array}$ \\
\hline \multirow{2}{*}{ Internal } & Venetian blinds & & $\begin{array}{l}\text { C-shaped slats } \\
\text { White } 71000\end{array}$ & $\begin{array}{l}\mathrm{T}_{\mathrm{vis}}=0 \% \\
\mathrm{R}=78 \%\end{array}$ \\
\hline & Roller blinds & & Fabric: White & $\begin{array}{l}\mathrm{T}_{\mathrm{vis}}=5 \% \\
\mathrm{R}=50 \%\end{array}$ \\
\hline
\end{tabular}

The solar shading devices were controlled based on daylight illuminance level in the space using a PI controller with a set point: $\mathrm{I}_{\text {set-point }}=500 \mathrm{~lx}, \mathrm{~K}=0.02$. Daylight illuminance was measured at the height of $0.6 \mathrm{~m}$ above the floor level, $1 / 3$ of the room depth measured from the window and $1 / 2$ of the room width. This strategy assumed that building occupants would use solar shading to prevent excessive illuminance levels to eliminate glare but prioritize to use daylight to its maximum. The set point of $500 \mathrm{~lx}$ assumed that the occupants used daylight levels in a medium higher range maintaining daylight for the type of tasks typical for residencies.

The open drop arm awning was simulated with fabric projected forward away from the window. The set up for the awning for each window was the same with projection angle changing between 0 and $90^{\circ}$ (Figure 5).

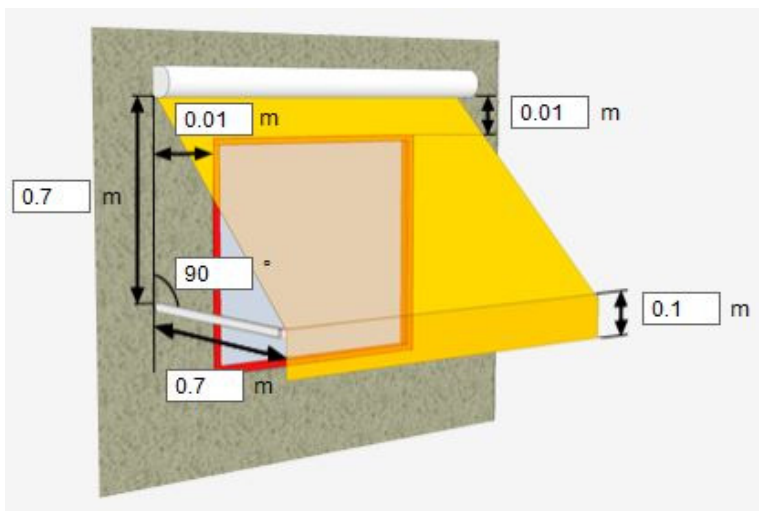

Fig. 5. Drop arm awning blinds modelled in IDA ICE.

The set up for the marquisolette for each window was the same as shown in Figure 6 with projection angle of the lower part between 0 and $90^{\circ}$. 
The slat angle for external and internal venetian blinds was fixed to $45^{\circ}$. Both external and internal venetian blinds were places $70 \mathrm{~mm}$ from the glass surface. The width of the external slats were set to 100 $\mathrm{mm}$ with spacing between the slats of $100 \mathrm{~mm}$. In case of the internal blinds the slat width was set to $35 \mathrm{~mm}$ with spacing of $32 \mathrm{~mm}$. The internal roller blinds were placed $83 \mathrm{~mm}$ from the glass surface.

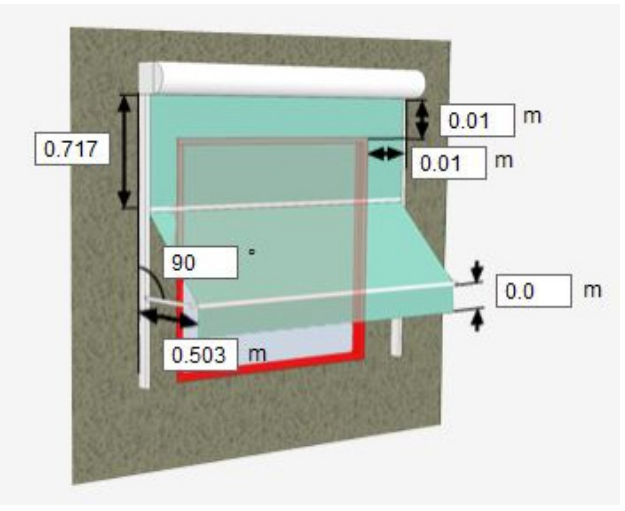

Fig. 6. Marquisolette modelled in IDA ICE.

\subsection{Analysis of overheating and primary energy use}

According to the Danish building regulations [16] the operative temperature in dwellings should not exceed $27^{\circ} \mathrm{C}$ for more than 100 hours per year and $28^{\circ} \mathrm{C}$ for more than 25 hours per year. Therefore in this study, the occupied hours with the indoor temperature above $27^{\circ} \mathrm{C}$ were treated as overheating with the tolerance limit of 100 hours. For the purpose of analysis, overheating hours for all rooms in the apartment were aggregated. The analysis of yearly primary energy use per $\mathrm{m}^{2}$ of the heated floor area included only ventilation and heating. The primary energy use for lighting and domestic hot water was neglected.

\section{Results}

The results regarding the total primary energy use and the aggregated occupied hours with temperature above $27^{\circ} \mathrm{C}$ from all rooms are summarized in Figures 7, 8 and 9 in the cases without the surrounding buildings for the west, east and south orientation of the living room, respectively. The results show that energy renovation including reduction of heat transmission and infiltration reduced the total primary energy use by approx. $60 \%$ in the naturally ventilated building. However, as expected, the energy renovation clearly intensified overheating. The hours with temperature over $27^{\circ} \mathrm{C}$ appeared mainly in the living room as the bedroom and kitchen faced the backside of the building, always shaded by the other parts of the modelled building.

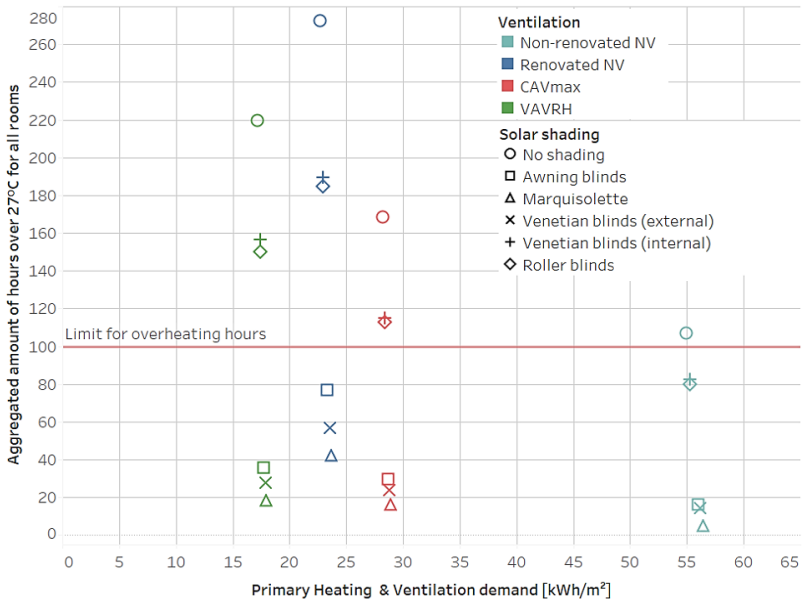

Fig. 7. Yearly primary energy use and number of occupied hours with indoor temperature over $27{ }^{\circ} \mathrm{C}$ in the apartment oriented towards west for cases without the surrounding buildings.

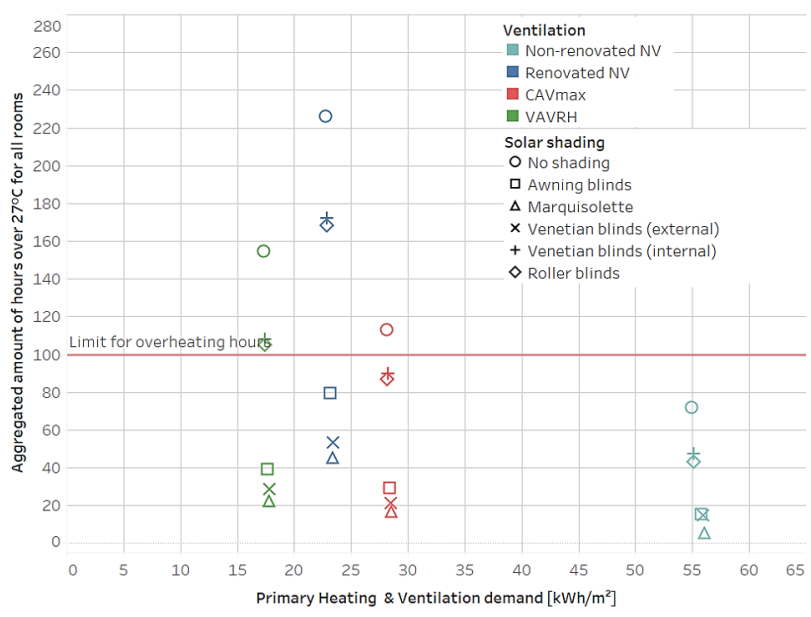

Fig. 8. Yearly primary energy use and number of occupied hours with indoor temperature over $27{ }^{\circ} \mathrm{C}$ in the apartment oriented towards east for cases without the surrounding buildings.

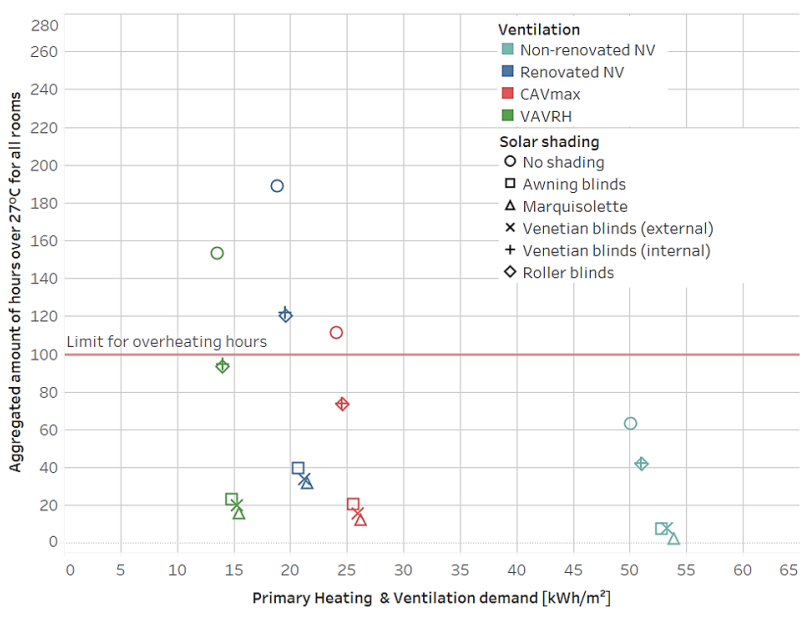

Fig. 9. Yearly primary energy use and number of occupied hours with indoor temperature over $27{ }^{\circ} \mathrm{C}$ in the apartment oriented towards south for cases without the surrounding buildings. 
The highest number of occupied hours with overheating occurred for the apartment with the living room oriented to the west in case of the naturally ventilated renovated building when the shading buildings were not present and no solar shading devices were used - 172 hours above the limit of 100 hours (Figure 7). In case of the east (Figure 8) and south (Figure 9) orientation, the number of hours above the limit was 126 and 88 , respectively. Implementation of a mechanical ventilation system after renovation reduced overheating compared to the case with natural ventilation, however, in none of the building orientations the tolerance limit of 100 hours was fulfilled. It is seen in Figures 7, 8 and 9 that the use of the $\mathrm{CAV}_{\max }$ system, which provided constant airflow, had stronger effect on reducing overheating compared to the $\mathrm{VAV}_{\mathrm{RH}}$ system, which modulated the airflow according to the relative humidity. Obviously, the $\mathrm{CAV}_{\max }$ system is associated with higher primary energy use for ventilation, which increased by approx. 93\% compared to the $\mathrm{VAV}_{\mathrm{RH}}$ system (Table 5). Additionally, also the primary energy use for heating increased by approx. $50 \%$ for $\mathrm{CAV}_{\max }$ compared to VAV $\mathrm{RH}$, resulting in an increase of the total energy use of approx. $68 \%$ in case of the $\mathrm{CAV}_{\max }$ system. When compared to the naturally ventilated building, the total primary energy use increased by $25 \%$ for the $\mathrm{CAV}_{\max }$ case and decreased by $25 \%$ for $\mathrm{VAV}_{\mathrm{RH}}$. According to the Danish building regulations [16], ventilation in new and renovated Danish dwellings should be designed to supply fresh air and avoid moisture related problems, thus cooling is not its primary purpose. However, it is clear from the results that mechanical ventilation even operating with minimum required airflow can reduce overheating.

Table 5. Primary energy use for heating and ventilation systems for different ventilation strategies in the renovated building.

\begin{tabular}{|c|c|c|c|}
\hline Orientation & $\begin{array}{c}\text { Ventilation } \\
\text { type }\end{array}$ & $\begin{array}{l}\text { Heating } \\
\text { demand } \\
\mathrm{kWh} / \mathrm{m}^{2}\end{array}$ & $\begin{array}{c}\begin{array}{c}\text { Ventilation } \\
\text { demand } \\
\mathrm{kWh} / \mathrm{m}^{2}\end{array} \\
\end{array}$ \\
\hline \multirow{3}{*}{ South } & $\mathrm{NV}$ & 18.8 & - \\
\hline & $\mathrm{CAV}_{\max }$ & 10.9 & 13.1 \\
\hline & $\mathrm{VAV}_{\mathrm{RH}}$ & 6.8 & 6.8 \\
\hline \multirow{3}{*}{ East } & $\mathrm{NV}$ & 22.7 & - \\
\hline & $\mathrm{CAV}_{\max }$ & 15.1 & 13.1 \\
\hline & $\mathrm{VAV}_{\mathrm{RH}}$ & 10.4 & 6.8 \\
\hline \multirow{3}{*}{ West } & NV & 22.8 & - \\
\hline & $\mathrm{CAV}_{\max }$ & 15.0 & 13.1 \\
\hline & $\mathrm{VAV}_{\mathrm{RH}}$ & 10.4 & 6.9 \\
\hline
\end{tabular}

The results in Figures 7,8 and 9 show that the two internal solar shading devices: roller blinds and venetian blinds performed similarly in regards to reducing overheating. The use of the internal solar shading helped to eliminate overheating only in combination with the constant ventilation airflows $\left(\mathrm{CAV}_{\max }\right)$ for the south- and east-oriented apartment. The $\mathrm{VAV}_{\mathrm{RH}}$ ventilation system combined with the internal shading was an efficient solution only for the south-oriented apartment.
Generally, the internal solar shading reduced number of occupied hours with the excess temperature in the renovated building by $34-39 \%$ in case of the south orientation, $29-33 \%$ in case of the west orientation, and $21-32 \%$ in case of the east orientation of the building .

All external solar shading devices were proved to be very efficient solutions for keeping the indoor temperature within the limit independently of the chosen ventilation solution. The results in Figures 7,8 and 9 show that there was only a small difference in performance between the three tested devices. The marquisolette was always the most efficient and reduced overheating by $89-92 \%$ for the south and west orientation, and $85 \%$ for the east orientation. The external venetian blinds showed a reduction of $87 \%$ and $81 \%$, while the drop arm awning $81-85 \%$ and $74 \%$ for the different building orientations, respectively. Generally, there was slightly weaker effect of the shading for the building oriented to the east and for the cases with natural ventilation.

The use of internal and external solar shading had a negligible effect on the total energy consumption due to relatively small size of the windows in this type of buildings.

The assumptions to the window opening resulted in average airflows through the windows (including infiltration) in the summer period in the building oriented to west (cases without solar shading) on the level $0.62 \mathrm{l} /\left(\mathrm{s} \cdot \mathrm{m}^{2}\right)$ for the naturally ventilated apartment, $0.41 \mathrm{l} /\left(\mathrm{s} \cdot \mathrm{m}^{2}\right)$ for the case with $\mathrm{VAV} \mathrm{V}_{\mathrm{RH}}$ system, and 0.35 $1 /\left(s \cdot \mathrm{m}^{2}\right)$ for the case with $C A V_{\max }$ ventilation. The values are lower than $0.9 \mathrm{l} /\left(\mathrm{s} \cdot \mathrm{m}^{2}\right)$ assumed in the Danish energy frame calculations for dwellings [13]. The higher airflows through the windows would help to reduce the number of hour with elevated indoor temperatures. However, the aim of the study was not to study the potentials of venting through windows but the potentials of solar shading.

Figure 10 shows the results for the building in the street canyon. The building with the living room facing south was chosen as an example due to the highest number of occupied hours with temperature above $27^{\circ} \mathrm{C}$. The results show that the modelled building was effectively shaded by surrounding buildings of the same height. The total energy use in the shaded building increased by approx. $5 \mathrm{kWh} / \mathrm{m}^{2}$ compared to the corresponding cases without surrounding buildings due to higher heating demand. Even in the building located in the street canyon, the solar shading devices had a potential to decrease indoor temperatures. 


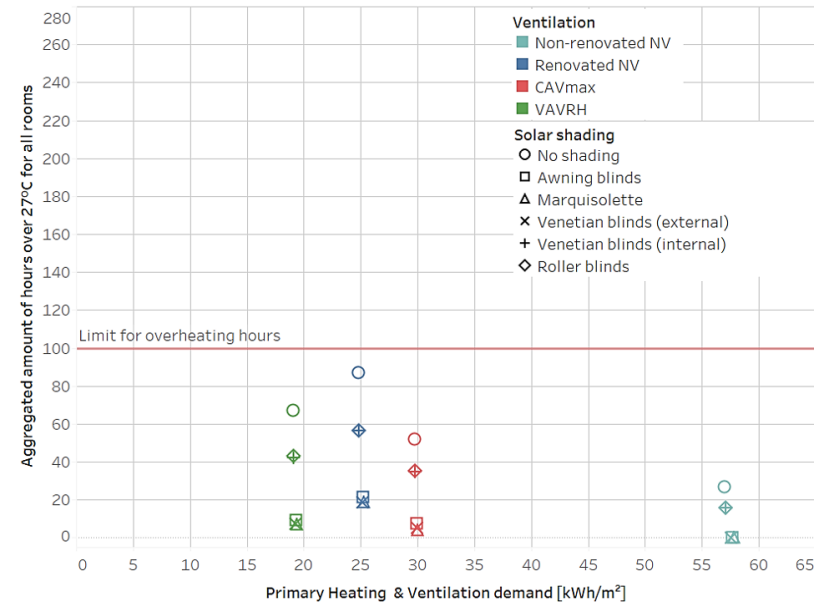

Fig. 10. Yearly primary energy use and number of occupied hours with indoor temperature over $27{ }^{\circ} \mathrm{C}$ in the apartment oriented to the south cases with the surrounding buildings present.

\section{Discussion}

In the past, overheating has not been considered a problem in Danish dwellings. It receives more attention nowadays as the risk of overheating in residences is increasing due to progressing climate change and stricter energy efficiency requirements. Not only the global warming has a negative impact on the rather high climatic cooling potential in Scandinavia [17], but also already accomplished low energy housing projects indicate an increase in the prevalence of overheating problems [18]. Still, in Danish context, overheating does not receive attention comparable to other European countries. For example in the UK, the general awareness and amount of research related to overheating is substantially higher [4, 19]. A recent report from the Department of Communities and Local Government [20] states that if no actions are taken, the heat related deaths in the UK could rise to around 5,000 per year in the 2080 s as suggested by climate change projections. Probably similar trends can also be expected in Denmark. The present study shows that old buildings that have been extensively refurbished are also in the risk of overheating. This risk seems to be significantly higher for free standing buildings which are not shaded by other buildings in their surroundings. However, it should be noted that the present study did not consider the effect of outdoor temperature increase in highly dense urban neighbourhoods. This so called heat island effect can increase outdoor temperature by several degrees in comparison to rural and suburban areas [21]. At the same time, the present study demonstrated potential of mechanical ventilation as well as solar shading devices to decrease overheating risks effectively. The study was focused on historical apartment buildings, where retrofitting of external solar shading often is not possible because their facades represent protected cultural heritage. Nevertheless, the results indicate that a significant reduction of overheating is possible by utilization of internal solar shading in combination with mechanical ventilation. It is important to mention that representation of user behaviour with respect to window opening and operation of solar shading in this study was rather simplified. Window opening behaviour dependent on internal temperature was applied to obtain consistency with the approach utilized in the Danish energy frame calculations [13]. This approach does not cover the whole complexity of window opening behaviour, which combines physiological, psychological, social environmental and contextual aspects [22]. The window opening strategy applied in the present study should be understood as a demonstration of the potential, which the window opening has with respect to reduction of overheating, but one needs to be aware of the fact that in reality, the additional airflow provided by windows can be markedly lower. Similarly, the amount and complexity of factors influencing how occupants operate solar shadings is also very high. As indicated by results of an extensive review published in [23], there is a certain inconsistency in the results of different studies. For example internal temperature as well as illuminance were found to significantly influence occupant behaviour in some studies, while their effect was insignificant in other studies. A study by Andersen et al. [24] gave an indication that occupants in Danish dwellings operate the shadings with regards to the daylight and/or solar radiation. As the present study focused on a demonstration of the potential, which utilization of solar shading devices may have on overheating, the control strategy preventing high indoor illuminances, but at the same time ensuring $500 \mathrm{~lx}$ from daylight was found appropriate.

\section{Conclusions}

- Energy renovation (adding thermal insulation and tightening the envelope) of a Danish apartment building from 1850-1900 yielded energy saving of approx. $60 \%$ but at the same time resulted in overheating.

- The highest overheating risk was associated with the westward orientation of a building simulated outside a street canyon.

- Mechanical ventilation systems defined according to requirements from the Danish building regulations were able to decrease overheating compared to natural ventilation. Nevertheless, their solely application was not enough to bring overheating below the limit specified by the Danish building regulations.

- Internal solar shading could reduce overheating below the specified limits only in combination with mechanical ventilation and only for the south or east orientation (a reduction in overheating hours by 20 $40 \%$ ).

- External solar shading could efficiently reduce overheating below the specified limits in all tested cases (a reduction in overheating hours by $74-92 \%$ ). 
The presented investigation is part of a project "Reduction of overheating in multi-storey apartment buildings in connection with facade renovation" founded by Grundejernes Investeringsfond (The Landowners' Investment Foundation).

\section{References}

1. BPIE. Europe's buildings under the microscope. A country-by-country review of the energy performance of buildings. BPIE (Buildings Performance Institute Europe, 2011)

2. European Commission (accessed 26.11.2018) https://ec.europa.eu/commission/index_en

3. REHVA. REHVA Guidebook no. 12. Solar shadingHow to integrate solar shading in sustainable buildings. W. Beck, D. Dolmans, G. Dutoo, A. Hall, O. Seppänen (eds.). REHVA (Federation of European Heating and Air-conditioning Associations, 2010)

4. NHBC Foundation. Overheating in new homes $-A$ review of the evidence. HIS BRE Press (2012)

5. Danmarks Statistik. Flere arbejder hjemme https://www.dst.dk/da/Statistik/bagtal/2010/2010-0224-Hjemmearbejde (accessed 26.11.2018) (2010)

6. CIBSE TM36. Climate Change and the Indoor Environment: Impacts and Adaptation. CIBSE (Chartered Institution of Building Services Engineers, 2005)

7. IEA EBC. IEA EBC Annex 62 - Venticool, The international platform for ventilative cooling https://venticool.eu/annex-62-home/ (accessed 20.11.2018) (2018)

8. M. Hutchins. High performance dynamic shading solutions for energy efficiency and comfort in buildings, Final Report of the research project "Cost Efficient Solar Shading Solutions in High Performance Buildings", http://aercnet.org/wpcontent/uploads/2015/12/ES-SO-Study-2015.pdf (2015)

9. J.A. Veitch and A.D. Galasiu. The physiological and psychological effects of windows, daylight and view at home: Review and research agenda. NRC-IRC Research Reports RR-325 (National Research Council of Canada, 2012)

10. IDA-ICE. IDA Indoor Climate and Energy 4.8., https://www.equa.se/en/ (2018)

11. P. Heiselberg and M. Kolokotroni. Ventilative Cooling. State of the art review. Department of Civil Engineering. Aalborg University, Denmark (2015)

12. P.G Wang, M. Scharling, K.B. Wittchen, C. KernHansen. Danish Design Reference Year. Technical Report 13-18. Danish Meteorological Institute (2013)

13. S. Aggerholm and K. Grau. SBI-anvisning 213. Bygningers energibehov (SBI-directions 213. Building energy consumption). Danish National Building Research Institute (in Danish) (2018)
14. K.M. Smith and S. Svendsen. The effect of a rotary heat exchanger in room-based ventilation on indoor humidity in existing apartments in temperate climates. Energy and Buildings, 116, 349-361 (2016)

15. M.H. Vorre, M.H. Wagner, S.E. Maagaard, P. Noyé, N.L. Lyng, L.H. Mortensen. Branchevejledning for indeklimaberegninger (Guideline for indoor climate calculations). National Danish Building Research Institut (in Danish) (2017)

16. BR18. The Danish Building Regulations 2018. Danish Transport, Construction and Housing Authority, http://bygningsreglementet.dk/ (accessed 20.11.2018) (2018)

17. N. Artmann, D. Gyalistras, H. Manz, P. Heiselberg. Impact of Climate Warming on Passive Night Cooling Potential. Building Research and Information, 36, 111-128 (2008)

18. T.S. Larsen, C. Brunsgaard. Comfort houses: development of a passive house concept in Danish context. In T.S. Larsen, \& S. Pedersen (red.), Towards 2020 - Sustainable Cities and Buildings: 3rd Nordic Passive House Conference 7-8 October 2010 Aalborg, Denmark (2010)

19. M. Taylor. Preventing overheating. Good Homes Alliance, London, UK (2014)

20. AECOM "Investigation of overheating in homes". Department for Communities and Local Government, UK (2012)

21. NHBC Foundation. Understanding overheating where to start: An introduction for house builders and designers. Richards Partington Architects (2012)

22. V. Fabi, R.V. Andersen, S. Corgnati, B.W. Olesen. Occupants' window opening behaviour: A literature review of factors influencing occupant behaviour and models. Building and Environment, 58, 188-198 (2012)

23. A. Wagner, W. O'Brien, B. Dong (eds). Exploring Occupant Behavior in Buildings, Springer International Publishing AG (2018)

24. R.V. Andersen, J. Toftum, K.K. Andersen, B.W. Olesen. Survey of occupant behaviour and control of indoor environment in Danish dwellings. Energy and Buildings, 41 (1), 11-16 (2009) 